\title{
LETTERS OF GENERAL JOSEPH M. STREET TO DR. ALEXANDER POSEY ${ }^{1}$
}

\author{
I
}

Dear Brother:-

Prairie du Chien, December 11, 1827.

I cannot complain of your silence, tho' I have not heard from you, my family, or any friends at Shawanee Town, since we parted at the Saline;-yet I am convinced you have written and Marie has more than once written. An impenetrable veil seems to have been obtruded between us, and as it relates to me, has cut off all knowledge of the treasures of my heart. I am nevertheless somewhat consoled by the reflection that it is different with my family and friends in your quarter. My letters I presume from their mode of departure have long since been received. In regard to yourself, I only lament that I have not been enabled to collect any thing more interesting to justify troubling you.

I arrived at this place, well, and have since enjoyed uninterrupted good health-for I cannot dignify with the name of sickness, moments of mental depression, and consequent headache from thinking too deeply sometimes of the absence of my family, and my entire ignorance of whether they are living, and in health, or pining in sickness, or sunk in death.-I am not apt to feed the mind with visionary apprehensions, but 3 or 4 months of silence, is-I had liked to have said intolerable. It is painful, and the contemplation difficult to stave off.-Still I try to be resigned to the superintending will of God, and daily look for the sweet relief of a letter. My letter by Mr. Douseman, you have no doubt recd.-when or by whom this will go I know not.

This place is not very desirable, it is certainly a point of great importance in relation to Indian affairs, and from commanding the only navigable pass between the Upper-Mississippi and the eastern States, by way of the Lakes, must be valuable in a commercial point of view. It is now the best, and much the must preferable rout for bringing merchandise to this country. Last summer two merchants went from this place Eastward for goods. One returned by way of the Lakes, Green Bay and the Wisconsin, the other apprehensive of danger from the Winnebagoes sent his goods to New Orleans, and by Steam Boat to St. Louis. The Ice took him and he is now 150 miles below this encamped and has built a cabin and stored up his goods until the Ice is hard enough to bring them up on the River in Sleighs. The one who came by the Lakes got here in Sep. and has nearly sold out, in consequence of no competition.

${ }^{1}$ This is a letter written by the Indian agent, General Joseph $M$. Street, to his brother-in-law, Dr. Alexander Posey, of Shawneetown, Illinois. General Street acquired great influence with the Indians. The last two years of his life, 1839-40, were spent at the Indian agency at what is now Agency City, Wapello County. and his grave and that of Chief Wapello, at Agency City, constitute a place of historic interest. 
The Wisconsin is a fine stream with no obstructions to the portage, about 160 miles from this-the portage is only $11 / 4$ miles and perfectly level. A man has settled there who keeps low truck wheels and oxen, and Boats are taken out of the water hoisted on 4 or 6 wheels (according to (the size, and) hauled across the portage and re-launched with but little trouble.) It w'd .......... mere trifle to cut across the portage, which is soft and sandy," so that Boats might come from Buffaloe to this place without any portage.

I have had no opportunity to examine the country beyond the high Bluffs that line this River from the Mouth of the Missouri to this place. There are small bottoms in many places along the River of very rich soil, but generally, the River appears to be washed down into a deep channel of bold bare rocks surmounted by hills nearly and sometimes entirely bare of timber. These hills are said to contain inexhaustible stores of lead mineral, from about 40 miles below Fever River to some miles north of this place, on both banks. The hills back of this village are perfectly bare, except a few cedar, and scrubby oak bushes. And the wnole distance a ledge of Rocks project from the steep sides of the Bluffs, that are worn as by the operation of water, acting horizontally, upon their different layers, and the sub-stratum appears generally at the same apparent level on each side for several 100 miles to have been of a softer texture than the super stratum, and has given way in many curious and fantastic shapes, leaving the upper ledge projecting a considerable distance, and forming hollows, caves and singular appertures of considerable size. At this place you can see the rocks for $\dot{8}$ or 10 miles on each side, presenting at once to the imagination from the similarity of appearance, and elevation, the Idea of an ancient lake, the level of the waters of which was once those ledges of rock. Their height is about 140 feet above the plain. The Bluffs are generally about from 2 to 400 feet high; and I am informed that beyond these bluffs the country makes off generally level. So that the greatest hills, and almost the only broken country is on the great Estuary of the country. The Wisconsin, presents a similar appearance untill within a few miles of the portage, and at the portage there is no bluff. The same fact occurs 200 miles above this at the Falls of St. Anthony. There are no bluffs above the falls, and the country is remarkably level, the ground gradually rising in a gentle slope from the banks of the River.

A great deal of money is now made at the lead mines of Fever River about 90 miles below this, and at Turkey River about 20 or 25 miles below this place. The last is opposite the mouth of Turkey River which comes in from the West side. At Fever River, there are said to be about 4 or 5000 persons. This is certainly too high a calculation-I should suppose there might be 2 or 3000 , before the Indian disturbances. At Turkey River there are 40 or 50 . I am confident there is a great opening for a man with small enterprise to make 
a fortune in a few years at 'Turkey River or F. R. tho' I think Turkey R. preferable. It is only about one days ride further up the Mississippi, the town scite immediately on the Bank of the M. R. in a beautiful plain and excellent landing and the mines are as rich and plenty as at $F$. R. the fact is the whole country from here to $F$. R. is full of lead mineral. At F. R. there is no highland on the Mississippi, the town of Galena is on F. R. 4 or 5 miles from the $M R$......... ......... is not more than 10 to 40 feet wide, and an immense and almost perpendicular bluffs rises to a heighth of about 120 to 140 feet. The houses are stuck into the sides of this bluff for about half a mile, one side on a small road that at some places is too narrow for a team to turn in, and the back sunk in the side of the bluff. At some points there is roorn for a building, but no back yard, and the bluff rises over the top of the houses a long way. At Turkey $R$. the Bluffs are from $1 / 2$ to a mile back of the River and a high level smooth prairie extends to the foot of the Bluffs. There is a great quantity of money in circulation at the mines; but labour is uncommonly high. You cannot get a hand even to cook or wait about your house for less than $\$ 15.00$ per month in silver. Doct. Fillier (who lives at F. R. and says he got acquainted with you at Vandalia) that he there had a negro man hired about his house at $\$ 20.00$ per month, and if he offended him he would leave his employment and could get the same from perhaps 20 or 30 persons. The Doct. says he is doing well. He went down to St. Louis in the Boat I came up in to replenish his stock of medicines. He hardly had a dose of medicine left, after the summer and fall practice. Their exposure, manner of living, and intemperance cause great sickness.

I can now give you a more correct view of our relations with the Winnebago Indians and trace with more certainty, the causes which lead to the recent aggressions of those Indians upon our people. I will suppose you have a good map of this country before you, (McLean has one.) By the treaty of 24. Aug. 1816 a line was run dividing the Ottoways, Chippewas and Pottowattomies of the Illinois, from the Winnebagoes, and was recognized and affirmed by the Winnebagoes by the treaty of the 19 Aug. 1825. This line commences at the Winnebago village 40 miles up Rock River from its mouth, (see your map and imagine the distance) thence northwardly passing to the east of all the streams above Rock River, that fall into the Mississippi, (on a dividing ridge) to the Wisconsin where the East line of the Prairie du Chien reserve crosses $S$. River. The whole country Eastwardly of S. line was secured to the Winnebagoes without reserve or priviledge. On the West of said line to the Mississippi and North of a due West line from the southern end of L. Michigan to the Mississippi, up to the south line of this reserve was secured to the Ottowas, Chippewas and Pottawattomies of the Illinois, with a reservation of "such tract or tracts of land, on, or near the Mississippi and Wisconsin Rivers as the President may see cause to designate; provided said tracts of land shall 
not in all exceed the quantity contained in 5 leagues square." This condition alone, is the only ground of a claim, and under this the lead mines of Fever $R$. and Turkey $R$, are worked. The President makes no specific locations; but diggings are made anywhere, and everywhere the miner chooses, upon obtaining a permit, for which he pays nothing unless he gets lead,-if he does he pays every tenth pound to the Agent for the U. S. From casting your eye over the above designated lines you will discover, that the reservations do not in any case extend into the Winnebago country. Or in other words, the Winnebago side of the line, we do not pretend to claim any privileges or rights on. Our whole reservations are on the Ottowato side of the above line. In the rage for mining which seems to have operated so strongly upon the whites last summer, permits were obtained and diggings commenced, and pursued with great success without any regard to this line. And were at last pushed to a considerable extent on the East side of S. line in the acknowledged country of the Winnebagoes. The Indians remonstrated, and contended against the miners, who repulsed them force for force, and drove them off from their own lands. The Indians became much aroused, and exhibited great symptoms of discontent, and behaved roughly to parties crossing Rock River, within their limits, and passing to the mines. They charged and enacted heavy toll, and in some cases, forced property from passengers. Whilst the Indians in the vicinity of the mines were then driven from the mines, and spoiled of the valuable product of the mines on their lands, and goaded into a state of high excitment, and other unfortunate events occurred to blow into an open rupture these latent seeds of discontent, whilst no attempts appear to have been made to appease and satisfy the justly (I may say) incited feelings of the Winnebagoes.

An ancient grudge, that is handed down by tradition (tho' the cause of it is lost from the tradition) exists between the Sioux (Sues) and the Chippewas on Lake Superior. A party of Chippeways, had came to St. Peters on a visit to Mr. Talliaferro, the Agent, and one night, a party of Sioux came on their camp and killed several Chippeways. Col. Snelling, commdg. at the Fort, immediately demanded the murderers, and the demand not being instantly complied with, he detached a strong party of U.S. troops to move secretly upon the Sioux encampment and take as many Sioux as there had been Chippewas killed. And in a short time before the Sioux were aware of it they were completely surrounded. They made show of battle; but when the Interpreter informed them that if they did not immediately surrender the murderers, they $w d$. be fired upon, they gave up the murderers present-one they said was absent-a hostage was demanded and surrendered, making as many Sioux as they had killed of Chippewas. These were marched off to the Fort, and deld. to the Chippewas who shot them all-the hostage along with the murderers, was shot--this gave much discontent. Previously, I should have remarked that some 
Winnebagoes had murdered some whites above Prairie du Chien, were surrendered and were then in the Fort at St. Peters. A Sioux Indian (Pine Tops) was very much exasperated at the Killing of the Sioux, and particularly the delivering over of the innocent hostage, by Col. Snelling, as he alledged. He came down the Mississippi to a Band of Sioux above this on Upper Ioway $R$. and tried to incite them to war against the Whites. Wabasha the chief of that band, is a very sensible man, and refused to move in the business, and restrained his warriors. About this time two Winnebago Indians came over, with a belt of wampum, and called a council of the Sioux, which was assembled by Wabasha. They spoke to the Sioux, detailed their complaints against the Whites, stated the injury done them at the mines, that the 2 prisoners at St. Peters had been killed along . with the Sioux, and that they wanted the Sioux to join them and both nations take their revenge. For the Chippewas, could not have killed the Sioux unless aided by the Whites, and besides an innocent Sioux had been killed. Wabasha and his band all refused to join. Told the Winnebagoes to be quiet-that they were fools-the Whites were too strong for them and they would be beaten and their lands taken. That if they wd. remain at peace, their F. the President would do them justice. But for himself and his tribe they would not bo so foolish as to go to war with the whites who were too strong for them. Pine Tops then got up, took the war belt from the Winnebagoes, and the war hatchet, told them the Americans have killed the Sioux at St. $P$. one an innocent man, and they have killed the 2 Winnebago prisoners, now go and be revenged. Kill white men. Strike a stroke at Prairie du Chien and on the Boats on the river, and so soon as war is commenced the Sioux will join you in presecuting it.

Joseph Montfort Street

to Dr. Alexander Posey.

Dec. 11, 1827.

(From Joseph M. Street Collection, p. 7.)

II

Dear Brother:-

Prairie du Chien, Dec. 12, 1827.

I am yet ignorant of the welfare of my family, and friends, in your quarter. I have neither received a line, nor heard one word from a passing stranger from home, since we parted at the Saline. This deathlike silence is extremely painful to me in my seeming banishment. To be separated from my family so long is of itself sufficiently disagreeable; but to be cut off from all knowledge of them is distressing. No regular mail comes here, and the mail goes by chance opportunities. 'Till there is portage enough collected to send a special messenger, and then the money is thus applied.

My health continues good; and were my mind at ease in relation to my family, I should be in tolerable spirits. Sometimes a fit of 
thinking and mental pain in regard to my family causes some headache. Otherwise I have not had a days sickness since we parted.

I have not been enabled to make any examination of this portion of country yet nor do I expect to be enabled to do so before my return in the Spring. My time has been constantly employed in my room since I. arrived here. I found the Agency in a miserable condition as it relates to Indians and indeed almost everything else. And I have been constantly employed in presenting its situation and the wide field of usefulness which I think should open from it, to the Government. And, in rendering its influence upon the Indians beneficial in tending to emilorate their condition........ its present state. How I shall succeed I know not yet when our relative situation with the Indian Tribes who inhabit the country adjacent to our settlements, and who once occupied the fine country on which a rapidly increasing, and industrious population are now residing; I cannot doubt that all reasonable men must consider these unhappy wanderers of the wilds have some claim upon the philanthrophy of the nation before the face of whose crowding population they are melting like the snows of their own region, before the rays of the mid-summmer sun.

What I have seen of this country in passing up the River, all persons here agree in stiling the worst part of it. The River lands being generally rocky, broken, and much inferior for the purpose of cultivation to the lands lying off the River, and intersperced with numerous small Rivulets, Skirted generally with excellent timber. The Mississippi and the Wisconsin are the great Estuaries of this portion of the United States, and the only appearance of mountains, or very broken lands, is their immediate shores. The Mississippi, rises nearly due West of the South West end of Lake Superior, and the Wisconsin, not far south of the Middle of the same lake. The first runs nearly South, and the latter, first south, to the portage and then nearly West, to their junction about 3 miles below this place. The Mississippi from near the Mouth of the Missouri to the falls of St. Anthony 200 miles above this runs in a deep and almost perpendicular channel like the sides of a great cannal, of about $1 \frac{112}{2}$ miles in width. The River and its "thousand Islands," which are never out of sight, is about One Mile wide, and the balance is generally overflowed bottoms, the river running frequently so close to the foot of the immense piles of rock that everywhere forms the fronts of the high Bluffs, so as to preclude the possibility of a road near its margin. The River changes from side to side in this valley, and sometimes the accession of a stream opens out a beautiful cove, terminating in the distance, in a grand and romantic amphitheatre. The sinuosities in the stream making the bluffs completely close, to the view, present the appearance of a handsome plain with a Rivulet passing through it, the large Mississippi on one hand, and encompassed with an immense chain of perpendicular rocks on three sides.-Such is very much the appearance of this place. Only the plain is about 9 miles 
long and from 2 to 4 miles wide. The Bluffs are generally from 2 to 400 feet high, and in many places projecting ledges of bare rocks appear to extend over their sub-stratum from 10 to 20 feet. This projecting ledge, the layers on which it rests, being generally worn away as if by the horizontal operation of water once occupying that level, are constantly presented, either at immediately the River, or back on the plain, at about from 120 to 140 feet from the present water level. This elevatioin gradually deminishes to the falls of St. Anthony, where the Bluffs striking. the level of the ledge of rocks over which the river is precipitated, ceases. From thence to its source, the banks are tolerably high and the country gently rises, with a gradual swell from the top of the banks and extending out forms a gently roling, tho' generally rather flat country interspersed with many small ponds and lakes. The Wisconsin presents similar features, until within a few miles of the portage, (160 miles above this), where the bluffs cease, and there is a portage of $11 / 2$ miles to Fox River. Boats are easily taken across the portage and to Fox River that empties into Green Bay, of L. Michigan. This portage from the top of a bank of ordinary heighth is almost entirely level from the top of the bank of the Wisconsin to the Fox River. Boats are easily taken across the portage and relaunched. A man now resides at the portage, keeps oxen, and truck wheels and passes over all boats for tol. The neck of land is free from rock and a very small expense would connect the two Rivers. It is not the heads or small branches that approach, the Wisconsin is as large at the portage as it is here, the Fox River is small but very deep, and having risen some distance to the south of the portage, and the W.(isconsin) to the North, they pass each other in the way $I$ have mentioned.

The lead mines, or mining country, (for there is a tract of country about 120 miles by 60 miles) extending South and East from the junction of the Mississippi and the Wisconsin, that has almost.......

General Joseph M. Street to Dr. A. Posey,

December 12, 1827.

(From Street Collection, p. 8.) 
Copyright of Annals of Iowa is the property of State of Iowa, by \& through the State Historical Society of Iowa and its content may not be copied or emailed to multiple sites or posted to a listserv without the copyright holder's express written permission. However, users may print, download, or email articles for individual use. 